\title{
Wkład Archiwistów Warszawskich w rozwój archiwistyki polskiej. Zbiór studiów poświęconych warszawskiemu środowisku archiwalnemu, red. Alicja Kulecka, Wydawnictuo Uniwersytetu Warszawskiego, Warszawa 2012, ss. 538
}

W

ydawnictwo zbiorowe Wktad Archiwistów Warszawskich w rozwój archiwistyki polskiej stanowi obszerny zbiór studiów poświęconych jednemu z większych polskich naukowych środowisk archiwistów. Książka wydana pod redakcją Alicji Kuleckiej ma na celu ukazanie problemów działalności archiwów w stolicy dawniej i obecnie.

Omawiana praca została podzielona na rozdziały tematyczne. Każdą z części starannie opracowano, zarówno pod względem merytorycznym, jak i technicznym. Dużym atutem jest fakt, że autorzy poszczególnych artykułów reprezentują nie tylko środowisko warszawskie. Swój punkt widzenia przedstawili archiwiści z Poznania, Lublina, Krakowa, Torunia, Piotrkowa Trybunalskiego i Łodzi. Biorąc pod uwagę rodzaj instytucji reprezentowanych przez autorów, dużą aktywnością wykazały się uniwersytety i archiwa państwowe (w tym archiwa centralne). Nie zabrakło także głosu z archiwum kościelnego, wyodrębnionego, wojskowego i Instytutu Pamięci Narodowej.

Poszczególne teksty nie pozostawiają wątpliwości, że autorzy pisali na tematy im znane i bliskie. Duża baza źródłowa, w tym akty normatywne, źródła archiwalne i literatura naukowa, zostały uzupełnione wiedzą i doświadczeniami własnymi archiwistów. Warto zwrócić także uwagę na oprawę graficzną wydawnictwa. Okładka utrzymana w stonowanych i eleganckich barwach przedstawia orła trzymającego $\mathrm{w}$ dziobie medalion $\mathrm{z}$ herbem Warszawy. Całość jest dobrze rozplanowana, a zatem przejrzysta.

W pierwszej części znalazło się dwanaście artykułów, w których przedstawiono archiwa warszawskie w kontekście ich funkcjonowania w przestrzeni publicznej. Wojciech Krawczuk (Uniwersytet Jagielloński) pochy- 
lił się nad tematem metrykantów koronnych w Warszawie. Jego artykuł stanowił zwięzłe i rzeczowe opracowanie zagadnienia oparte na literaturze przedmiotu. Tekst Ireny Mamczak-Gadkowskiej (Uniwersytet im. Adama Mickiewicza) pt. Archiwa warszawskie w Polsce niepodlegtej (1918-1939) został natomiast opracowany na podstawie literatury i kwerendy archiwalnej. Autorka przedstawiła argumenty stanowiące o tym, że w okresie międzywojennym archiwiści warszawscy wiedli prym na polu działalności naukowej i wydawniczej. Wskazała także wybitnych archiwistów związanych z ośrodkiem warszawskim. Agnieszka Rosa (Uniwersytet Mikołaja Kopernika) przedstawiła z kolei związek archiwistyki toruńskiej i warszawskiej, który kształtował się na przestrzeni lat. Głównym spoiwem łączącym te dwa prężne ośrodki naukowe jest osoba profesora Andrzeja Tomczaka. Dużym atutem tekstu jest to, że powstał nie tylko na bazie literatury i akt własnych Zakładu Archiwistyki Uniwersytetu Mikołaja Kopernika w Toruniu, ale także wspomnień nestora polskiej archiwistyki. Autorka przedstawiła w sposób rzetelny zarówno historię współpracy archiwistów z Torunia i Warszawy, jak i późniejszy jej przebieg w latach 1957-1992. W kolejnym tekście Tomasz Matuszak (Archiwum Państwowe w Piotrkowie Trybunalskim) zaprezentował rys historyczny Archiwum w Piotrkowie Trybunalskim, w którym podkreślił udział archiwistów warszawskich. Dużo uwagi poświęcił osobie Adolfa Erazma Mysłowskiego, który w sposób szczególny zapisał się w dziejach instytucji. Ten artykuł również ma za podstawę literaturę oraz obszerną kwerendę archiwalną. Tekst Tadeusza Pawła Rutkowskiego (Uniwersytet Warszawski) to obszerne opracowanie, napisane w zajmujący sposób, dotyczące funkcjonowania Naczelnej Dyrekcji Archiwów Państwowych i jej pracowników jako obiektu działań operacyjnych Służby Bezpieczeństwa w latach siedemdziesiątych i osiemdziesiątych XX wieku. Na podstawie zasobnej bazy źródłowej autor przedstawił zagadnienie w sposób pełny i rzetelny. Jacek Krochmal (Archiwum Główne Akt Dawnych) pochylił się natomiast nad problemem nazewnictwa najstarszego polskiego centralnego archiwum. Artykuł nie stanowi pełnego opracowania dziejów Archiwum Głównego - obecnie Archiwum Głównego Akt Dawnych - w XIX wieku. Konstrukcja tekstu została przemyślania, a dzięki wprowadzeniu podtytułów nabrała przejrzystości. Autor oparł się na licznych źródłach polskich oraz, co istotne, rosyjskich. W kolejnym artykule 
Karol Dowgiało z Archiwum Archidiecezjalnego Warszawskiego przedstawił obszerny rys historyczny tej instytucji. Swoją pracę oparł w znacznej części na źródłach archiwalnych, ale także na literaturze, źródłach elektronicznych i wiedzy własnej. Inną tematyką zajął się Filip Kwiatek (Narodowe Archiwum Cyfrowe), który poświęcił artykuł zbiorom fotografii NAC. Jest to jego kolejna publikacja na ten temat; tym razem autor zajął się tematyką opracowywania, udostępniania i popularyzacji zasobu w przeszłości, dziś i w przyszłości. Skromny aparat naukowy, którym opatrzono tekst, pozwala wnioskować, że autor w dużej mierze bazował na wiedzy i doświadczeniach własnych. Następnie Archiwum Polskiej Akademii Nauk opisała Jolanta Stasiak (Polska Akademia Nauk, Archiwum w Warszawie). Autorka wprowadziła system porządkowy oparty na podziale na okresy odpowiadające kadencjom kolejnych dyrektorów: Zygmunta Kolankowskiego, Kazimierza Krzosa, Jana Andrzeja Imielskiego, Hanny Damnickiej-Wołoszyńskiej, Hanny Krajewskiej. Anna Belka (Archiwum Państwowe m.st. Warszawy) opisała natomiast próby rekonstrukcji zasobu Archiwum Miejskiego w Warszawie po II wojnie światowej. Artykuł powstał na podstawie źródeł archiwalnych oraz literatury, głównie autorstwa pracowników archiwum. Anna Barszcz (Archiwum Rady Ministrów) podjęła natomiast temat kadry archiwum zakładowego Prezydium Rady Ministrów/Urzędu Rady Ministrów. Artykuł został podzielony na poddziały porządkujące poszczególne kwestie. Ostatni artykuł w tej części omawianej pracy przygotował Rafał Leśkiewicz (Instytut Pamięci Narodowej, Warszawa). Opisał w nim powstanie i wyniki jedenastoletniej działalności IPN. Z dużą dokładnością przedstawił kluczowe kwestie, takie jak m.in. gromadzenie zasobu archiwalnego. Autor wielokrotnie odwoływał się do aktów normatywnych, choć nie zabrakło także odniesień do literatury.

Drugą część, poświęconą dorobkowi teoretycznemu i merytorycznemu warszawskiego środowiska archiwistów, otworzył tekst Agnieszki Bartoszewicz (Uniwersytet Warszawski), która przyjrzała się księgom miejskim w AGAD, stanowi ich opracowania i możliwościom badawczym. Artykuł oparty został na szerokiej kwerendzie archiwalnej oraz starannie dobranej literaturze. Wkład Józefa Siemieńskiego do teorii edytorstwa dawnych tekstów przedstawił Piotr Dymmel (Archiwum Państwowe w Lublinie). Autor zaprezentował dorobek badacza w sposób szeroki i rze- 
telny, nie pomijając głosów krytyki kierowanych wobec prac Siemieńskiego. Hubert Wajs (AGAD) podjął w swoim artykule temat prekursorów standaryzacji opisu archiwalnego. W sposób skrótowy przedstawił sylwetki Teodora Wierzbowskiego i Adama Wolffa. W kolejnym tekście Urszula Kasperczyk (AGAD) opisała koncepcję opracowania i inwentarzy idealnych akt urzędów i instytucji z epoki stanisławowskiej oraz jej realizację podjętą w przewodniku AGAD. Artykuł oparto na odpowiednio dobranej literaturze i wiedzy autorki. Inspiracje francuską i niemiecką myślą archiwalną w środowisku archiwistów warszawskich opisała Alicja Kulecka (Uniwersytet Warszawski). Tekst został podzielony na wstęp, dwa szerokie podrozdziały i podsumowanie. W artykule powołano się na wiele opracowań z literatury fachowej. Autorem artykułu zamykającego tę część zbioru jest Adam Grzegorz Dąbrowski (Archiwum Akt Nowych). Opisał on problemy zarządzania dokumentacją w urzędach administracji państwowej w świetle referatu Józefa Stojanowskiego z 1937 roku. Autor, po rzetelnym przeanalizowaniu zagadnienia, doszedł do wniosku, że sytuacja w archiwach wymaga poprawy.

Trzecia część poświęcona została zagadnieniu „Pomiędzy historią a pamięcią. Osobowość warszawskiego środowiska archiwalnego". W swoich artykułach autorzy przedstawili sylwetki zasłużonych archiwistów, wśród których znaleźli się: Piotr Bańkowski, Grzegorz Jakubowski, Jadwiga Karwasińska, Kazimierz Konarski, Stefan Krzysztof Kuczyński, Julian Adam Majewski, Adam Moraczewski, Bronisław Pawłowski, Bolesław Waligóra, Anna Maria Przybyłowicz, Franciszka Ramotowska, Witold Suchodolski, Irena Sułkowska-Kurasiowa oraz Teresa Zielińska.

Czwarta część dotyczy współczesnego oblicza archiwów warszawskich. Otwiera ją tekst Violetty Urbaniak (Archiwum Państwowe m.st. Warszawy), która podjęła tematykę funkcji edukacyjnej archiwów w kontekście partnerstwa szkół i archiwów. Wojciech Woźniak (Narodowe Archiwum Cyfrowe) przedstawił zaś zadania NAC w zakresie gromadzenia, przechowywania i udostępniania dokumentów elektronicznych. Autor oparł się w znacznej mierze na wiedzy i umiejętnościach własnych, a także na aktach normatywnych i literaturze. W oddzielnym tekście zajął się także bazą ZoSIA (Zintegrowany System Informacji Archiwalnej), w której upatruje się przyszłość archiwalnych systemów informatycznych. 
Wydawnictwo zostało wzbogacone o zbiór dziewiętnastu czarno-białych ilustracji, stanowiący ciekawy, mimo niewielkich rozmiarów, dodatek. Ważną częścią opracowania są również streszczenia artykułów w języku angielskim.

Wydawnictwo spełniło postawione przed nim wyzwanie ukazania wkładu środowiska warszawskiego w rozwój polskiej archiwistyki. Autorzy ukazali wieloaspektowość działań minionych, obecnych oraz tych, z którymi przyjdzie się zmierzyć w przyszłości. Dzięki zaangażowaniu reprezentantów wielu środowisk nakreślono w książce szerokie spojrzenie na podjętą tematykę. Omawianą publikację należy uznać za podstawę dla dalszych, bardziej szczegółowych badań nad archiwami warszawskimi. Zdecydowanie można powiedzieć, że książka Wkład archiwistów warszawskich $w$ rozwój archiwistyki polskiej wzbogaca literaturę archiwalną oraz ukazuje problemy działalności archiwów warszawskich dawniej i obecnie.

Agnieszka Zasada (Toruń) 